\title{
Leaders
}

\section{Prion diseases: what will be next?}

\author{
Paul van der Valk
}

"There is one particular thing that is nothing whatsoever in any way, shape, form like any other..."

From: Nothing like a dame, South Pacific Oscar Hammerstein

In recent history there is probably no group of disease that has caused more surprises or shocks than the group of transmissible spongiform encephalopathies, or prion diseases as they have become known.

Grouped together on the basis of their neuropathology, showing vacuolation of the neuropil or neurones, or both (spongiform change) (fig 1), they present a variable clinical picture $^{1-8}$; nevertheless they are all caused by aberrations of a single protein ${ }^{910}$ (table 1$)$.

They are sporadic as well as hereditary, and in the latter two completely different clinical pictures can be seen within one family (with an identical genetic abnormality in afflicted family members). For instance, in one family one can find classical Creutzfeldt-Jakob disease (CJD), with dementia, ataxia, myoclonic epilepsy, and so on, whereas other family members develop fatal familial insomnia (FFI), with sleep and autonomic disturbances, but little or no ataxia and dementia. ${ }^{7}$

Another shock was their transmissibility, dramatically illustrated by kuru, a spongiform encephalopathy in the Fore tribe in New Guinea, spread by cannibalism. ${ }^{11}$ Perhaps less

\section{Accepted for publication} 30 January 1998

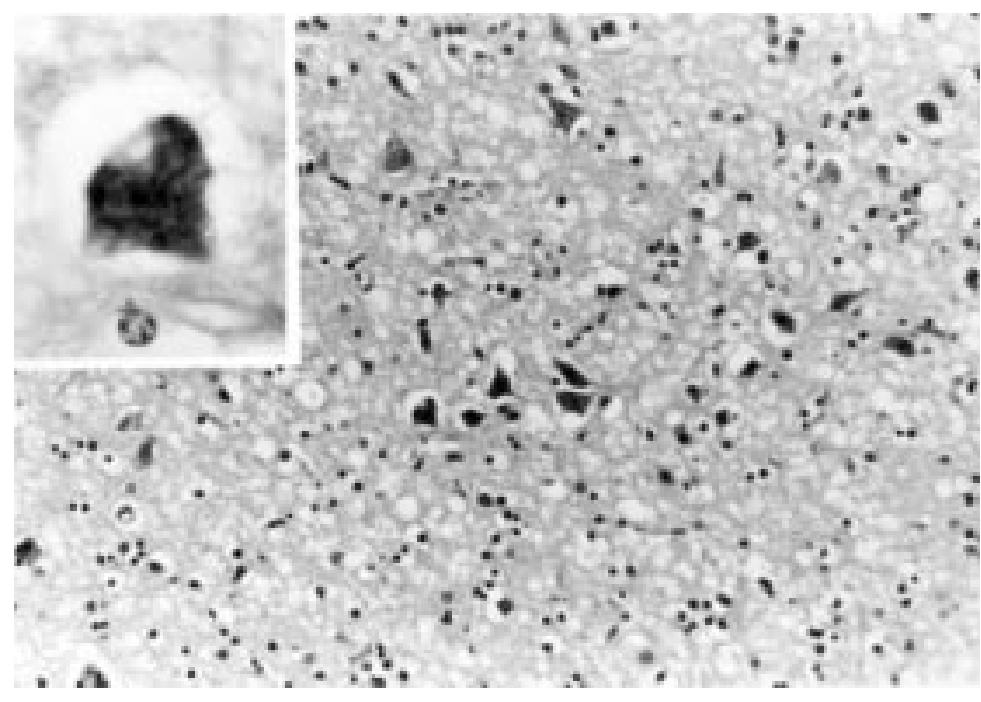

Figure 1 Parietal cortex of a patient with Creutzfeldt-fakob disease (CFD). Note the extensive vacuolation of the neuropil (haematoxylin-eosin, 143×); the inset is a magnification of one of the central neurones, showing discrete cellular vacuoles $(451 \times)$. exotic but no less dramatic was the demonstration of CJD in patients treated with cadaveric growth hormone, dura mater grafts, corneal transplants, or after use of contaminated surgical instruments or electrodes, ${ }^{12}{ }^{13}$ another reminder of the "infectious" nature of these diseases.

Scientifically, however, perhaps the greatest shock or surprise was the gradual realisation that the agent causing these diseases contained no DNA or RNA, and that we are dealing here with an infectious protein, for which the term "prion" was coined by Prusiner. ${ }^{14}$ Here we have a protein that was apparently able to replicate without the intervention of nucleic acids. Certainly, none of the methods used to destroy nucleic acids diminished the infectivity, ${ }^{15}$ but the idea that some kind of virus, extremely well hidden, is involved has never been completely laid to rest. The existence of "strains" of prions - that is, different inocula of prions that reproducibly cause a different prion diseases (each with their own incubation time and clinical severity) ${ }^{16}$ - has always been a strong argument for this. Very recently, Manuelidis et al resurrected the viral hypothesis when they found that the vacuolisation of cells and nervous tissue in their experimental design preceded accumulation of the infectious protein to be described below. ${ }^{17}$ Though no solid evidence was produced in that paper to show that a virus was involved, perhaps there is, yet again, a surprise in store for us.

Whatever the case will prove to be, this infectious protein is something else indeed...

\section{The protein}

The similarity of the human prion diseases and scrapie meant that most studies on transmissibility of these diseases were done using scrapie inocula, as it is easier to come by. Curiously enough, it was not possible to infect all species with scrapie, a phenomenon called the species barrier; for instance, infection of mice with CJD material is mostly unsuccessful. During further studies it quickly became clear that scrapie agent had some peculiar characteristics. It possessed an extreme durability, being resistant to irradiation (either ultraviolet or gamma), heat or cold, and chemical disinfection, including prolonged formalin fixation. Treatment with DNase or RNase did not abolish infectivity, but treatment with proteinase did, focusing attention on the protein content of the inoculum. ${ }^{18}$ In the test tube purified preparations of scrapie 
Table 1 Spongiform encephalopathies in humans and animals

\begin{tabular}{|c|c|c|c|}
\hline Disease entity & Clinical features & Pathology & Cause/genetic background \\
\hline $\begin{array}{l}\text { Creutzfeldt-Jakob disease } \\
\text { (first described in 1920): } \\
\text { variants are recognised; } \\
\text { familial occurrence reported, } \\
\text { but rare }\end{array}$ & $\begin{array}{l}\text { Dementia; ataxia; myoclonus; } \\
\text { (extra)pyramidal signs; cortical } \\
\text { blindness; rapidly progressive, } \\
\text { death within } 1 \text { year }\end{array}$ & $\begin{array}{l}\text {-Vacuolation of neuropil, neurones, and } \\
\text { sometimes astrocytes; neuronal loss; } \\
\text { astrogliosis; rare amyloid plaques, } \\
\text { staining for PrP. Changes occur primarily } \\
\text { in: cerebral cortex, basal ganglia, } \\
\text { thalamus, cerebellar cortex, subiculum }\end{array}$ & $\begin{array}{l}\text { Accumulation of prion protein }(\operatorname{PrP}) \text { : (A) through } \\
\text { unknown cause (sporadic CJD); (B) through } \\
\text { contact with PrP infected material (corneal } \\
\text { transplantation, dura mater grafting, } \\
\text { contaminated electrodes, use of growth hormone } \\
\text { from cadaveric pituitary glands, (?) handling } \\
\text { infected material, at surgery, pathology, etc. } \\
\text { (iatrogenic CJD); (C) through mutations in PrP } \\
\text { gene, eg at codon } 178 \text { or } 200 \text { (familial CJD) }\end{array}$ \\
\hline $\begin{array}{l}\text { Gerstmann-Straussler- } \\
\text { Scheinker disease (first } \\
\text { described in 1936): always } \\
\text { familial; variants are } \\
\text { recognised }\end{array}$ & $\begin{array}{l}\text { Ataxia; spinal symptoms; } \\
\text { (paraesthesia, pain); later, } \\
\text { dementia; rigidity; bradykinesia. } \\
\text { Rapidly (<1 year) or slowly ( } 5 \\
\text { years) progressive; variation within } \\
\text { one family! }\end{array}$ & $\begin{array}{l}\text { Amyloid plaques (multicentric, ie } \\
\text { consisting of several smaller deposits } \\
\text { grouped together), especially numerous } \\
\text { in the cerebellum; vacuolation of } \\
\text { neuropil variable; neuronal loss; some } \\
\text { astrogliosis; white matter degeneration }\end{array}$ & $\begin{array}{l}\text { Mutations in PrP gene, eg at codon } 102 \text { (ataxic } \\
\text { GSS) or } 117 \text { (telencephalic GSS) }\end{array}$ \\
\hline $\begin{array}{l}\text { Kuru (first reported in 1957) } \\
{ }^{\star} \text { In Fore tribe in New } \\
\text { Guinea }{ }^{*} \text { Spread by } \\
\text { cannibalism! }\end{array}$ & $\begin{array}{l}\text { Ataxia; tremors; later, dementia. } \\
\text { Most patients women and children }\end{array}$ & $\begin{array}{l}\text { Neuronal loss, severe in cerebellum; } \\
\text { vacuolation of neuropil in cerebral } \\
\text { cortex, basal ganglia, thalamus, } \\
\text { hippocampal areas; amyloid plaques, } \\
\text { especially in cerebellum; astrogliosis, } \\
\text { especially in cerebellum }\end{array}$ & $\begin{array}{l}\text { Ingestion of prion infected material, especially } \\
\text { nervous tissue (brains were preferentially eaten by } \\
\text { women and children) }\end{array}$ \\
\hline $\begin{array}{l}\text { Fatal familial insomnia } \\
\text { (first reported in 1986) } \\
{ }^{\star} \text { Disease found in family } \\
\text { with familial CJD }\end{array}$ & $\begin{array}{l}\text { Sleeping disorder (insomnia); } \\
\text { autonomic disturbances; } \\
\text { endocrine dysfunctions; ataxia, } \\
\text { dysarthria, dysphagia; myoclonus; } \\
\text { no dementia. Rapidly progressive } \\
\text { (1-3 years) }\end{array}$ & $\begin{array}{l}\text { Neuronal loss, severe in thalamus and } \\
\text { inferior olives, less in cerebellum, no } \\
\text { substantial loss in cortex; astrogliosis; } \\
\text { little vacuolation in cortex; no amyloid } \\
\text { plaques }\end{array}$ & $\begin{array}{l}\text { Mutation in PrP gene at codon } 178+\text { methionine } \\
\text { at codon } 129 \text { of mutated allele (with a valine at } \\
129 \text { CJD results!). Homozygotes at } 129 \text { have a } \\
\text { more rapid clinical course. }\end{array}$ \\
\hline (New) variant CJD & $\begin{array}{l}\text { Relatively young patients; } \\
\text { psychiatric disturbances (early); } \\
\text { dysaesthesia; ataxia; dementia; } \\
\text { myoclonus (late). Relatively } \\
\text { prolonged clinical course }\end{array}$ & $\begin{array}{l}\text { Vacuolation of neuropil and neurones; } \\
\text { amyloid plaques; "florid plaques" } \\
\text { (vacuolation surrounding amyloid } \\
\text { plaques); neuronal loss; gliosis }\end{array}$ & ?Ingestion of BSE infected material? \\
\hline $\begin{array}{l}\text { Scrapie (known for } \\
\text { centuries): disease of sheep } \\
\text { and goats, archetypical } \\
\text { prion diseases }\end{array}$ & $\begin{array}{l}\text { Ataxia; tremors; weakness; } \\
\text { wasting; thirst; itching, causing the } \\
\text { animal to rub or "scrape" against } \\
\text { hard surfaces }\end{array}$ & $\begin{array}{l}\text { Vacuolation, especially of neurones, less } \\
\text { so of neuropil; neuronal loss; astrogliosis; } \\
\text { few amyloid plaques; changes severe in } \\
\text { brain stem nuclei (vestibular, pontine, } \\
\text { olives, red nucleus), Clarke's column, } \\
\text { cerebellum, hypothalamus; cerebral } \\
\text { cortex, thalamus, striatum are spared }\end{array}$ & $\begin{array}{l}\text { Accumulation of } \operatorname{PrP} \text { through unknown causes. } \\
\text { Genetic factors are of influence. Transmissability } \\
\text { has long been recognised. }\end{array}$ \\
\hline $\begin{array}{l}\text { Bovine spongiform } \\
\text { encephalopathy (BSE): } \\
\text { occurs in cattle; epidemic in } \\
\text { Britain 1985-1992 }\end{array}$ & $\begin{array}{l}\text { Ataxia; weakness; behavioural } \\
\text { changes; wasting }\end{array}$ & $\begin{array}{l}\text { Vacuolation of neurones and neuropil; } \\
\text { neuronal loss; astrogliosis; rare amyloid } \\
\text { plaques; changes most severe in brain } \\
\text { stem (trigeminal nuclei, solitary } \\
\text { nucleus), less in diencephalon, least in } \\
\text { cerebral cortex }\end{array}$ & $\begin{array}{l}\text { Ingestion of PrP containing food supplements } \\
\text { (Scrapie infected?) }\end{array}$ \\
\hline
\end{tabular}

agent showed a marked tendency to form fibrillary aggregates with the tinctoral properties of amyloid. ${ }^{19}$ The propensity of the protein to aggregate was a serious obstruction to further analysis, but after a lot of effort the protein was finally identified. The molecular size was $27-30 \mathrm{kDa}$, derived from a slightly larger molecule of 33-35 kDa, now called the prion protein or PrP, and as it was isolated from scrapie material it was designated $\operatorname{PrP}^{\mathrm{Sc}}{ }^{20}$

Perhaps the greatest surprise was the discovery that in humans a protein with an identical amino acid composition and sequence, known as $\operatorname{PrP}^{\mathrm{c}}$, was present in many cells of the body, including neurones. ${ }^{21} \operatorname{PrP}^{c}$ is a membrane anchored glycoprotein that is continuously recycled through endocytosis, but its function to this day is unknown. ${ }^{22}$ For some reason one protein is normally present in tissues, whereas another $\left(\mathrm{PrP}^{\mathrm{Sc}}\right)$, with exactly the same amino acid sequence, mediates a fatal neurodegenerative disorder when it accumulates in the tissue of brain and spinal cord (fig 2).

Comparison of $\operatorname{PrP}^{\mathrm{Sc}}$ and $\operatorname{PrP}^{\mathrm{c}}$ revealed marked differences of tertiary structure, with a much higher percentage of $\beta$ pleated sheet forming regions in $\operatorname{PrP}^{\mathrm{Sc}}{ }^{22}$ Apparently, this difference in tertiary structure causes a major dif- ference in behaviour of both molecules, with a high tendency of $\mathrm{PrP}^{\mathrm{Sc}}$ to form insoluble deposits. To explain the "infectivity" of this abnormal protein a hypothesis was formed: contact with $\operatorname{PrP}^{\mathrm{Sc}}$ can somehow force a conformational change in $\operatorname{PrP}^{c}$, turning it into $\mathrm{PrP}^{\mathrm{Sc}}$ (fig 3). ${ }^{22}$ This would cause a continuous conversion, as each thus newly formed $\mathrm{PrP}^{\mathrm{Sc}}$ can contribute to the process, changing each molecule of $\operatorname{PrP}^{\mathrm{c}}$. The resulting steady increase of $\mathrm{PrP}^{\mathrm{Sc}}$ explains the "replication" of the agent.

If the binding between $\operatorname{PrP}^{\mathrm{c}}$ and $\operatorname{PrP}^{\mathrm{Sc}}$ is crucial, it is also easy to understand that small but strategic differences in the amino acid composition might interfere with binding. This may explain the species barrier, as there are differences between species in PrP structure and these differences may preclude the necessary interaction of the disease-inducing PrP and the normal PrP. In addition, this could explain the genetic forms of the disease, if it could be shown that these patients had genetic aberrations in their PrP. This proved to be the case. ${ }^{10}$ All genetic prion diseases are associated to mutations in the $\operatorname{PrP}$ gene, with different mutations associated with different phenotypes. It was also found that a particular polymorphism in the molecule influenced the con- 


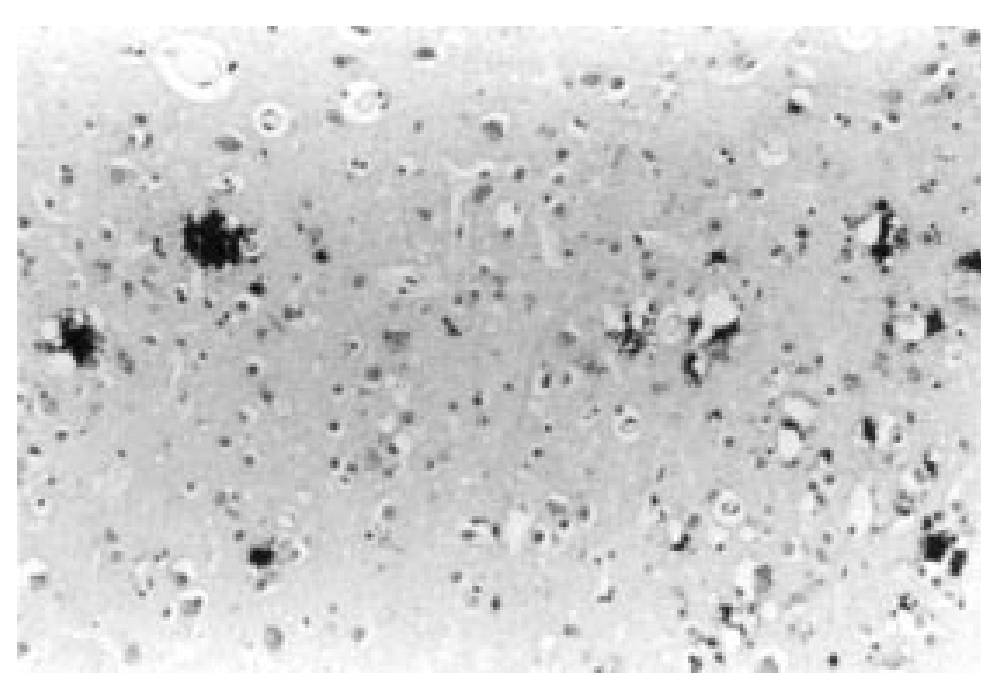

Figure 2 PrP immunostaining. This area of frontal cortex of another CFD patient shows the irregular $\operatorname{PrP}$ deposits of variable size, often next to vacuoles (156×).

formational change. This polymorphism involves codon 129 of the molecule ${ }^{23}$; people can be either homozygous for methionine or valine at this codon, or heterozygous and have one allele coding for a methionine, and one for valine. Thus, curiously, patients with a specific mutation and a methionine at position 129 will develop FFI, whereas family members with a valine at 129 in addition to their mutation will develop familial CJD. ${ }^{74}$ This polymorphism is important for acquired prion diseases as well, as will be outlined below.

The consequence of the "conformational" hypothesis is that the agent can only cause disease if the normal protein is present, a fact that was recently proven when PrP-knock-out mice were inoculated and no spongiform encephalopathy developed. ${ }^{25}$ Whether this conversion needs a third factor is still a matter of debate, but the existence of such a factor, called protein
$\mathrm{X}$, was suggested in $1994^{26}$ (fig 3). Perhaps factor $\mathrm{X}$ will prove to be the same agent Manuelides et al claimed to have found (supposedly a virus!). ${ }^{17}$ In any case the conformational theory of PrP conversion is not much in doubt and its occurrence will certainly contribute to tissue damage. Whether something else triggers this, and whether this is a virus, remains to be proven.

\section{Bovine spongiform encephalopathy}

The prion diseases still had a surprise in store. In 1985 it became clear that a strange disease in cattle had emerged in Great Britain, called "mad cow disease." The disease was neuropathologically characterised by spongiform change, neuronal loss, and astrogliosis, making it a prion disease ${ }^{27}$ : bovine spongiform encephalopathy (BSE). In a relatively short time the occurrence of BSE assumed epidemic proportions, with thousands of animals affected. ${ }^{8}$ The cause proved to be a scrapie contaminated bone meal preparation, ${ }^{28}$ fed primarily to dairy cows. From the beginning there was concern over the possibility that consumption of contaminated meat might cause a prion diseases in humans, but as the epidemic abated after a ban on the use of animal derived food supplements was instigated, the apprehension also lessened. However, fears flared up again when a report was published on a new prion diseases in humans which resembled CJD but was nevertheless clinically distinct: the patients were all young, had a relatively protracted clinical course, and had a typical clinical presentation with predominant psychiatric signs, rare in classical $\mathrm{CJD}^{29}$ Also, there were neuropathological differences, with more amyloid depositions (not unlike kuru) and a typical vacuolisation pattern, with vacuoles surrounding the plaques, so-called florid plaques. ${ }^{29}$ The

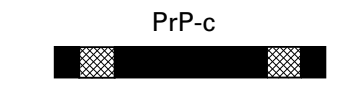

A

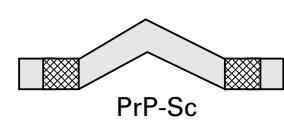

PrP-Sc
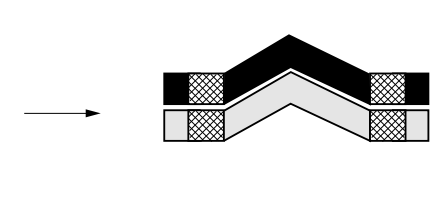

Dimerisation
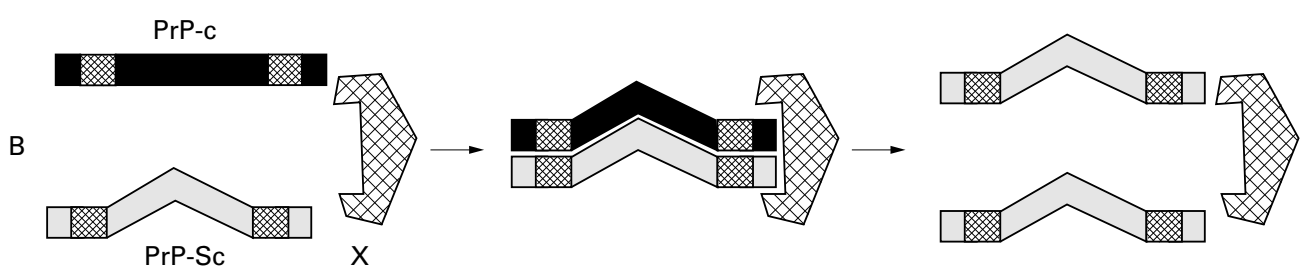

Figure 3 Hypothesis of conformational change. (A) Dimerisation occurs without a third party. The hatched areas in both $\operatorname{PrP}$ and $\operatorname{PrP} P^{s c}$ are the putative domains involved in binding between the two molecules. Differences in these areas, as would occur in PrP of different species, may abrogate or at least influence binding, explaining the species barrier and the existence of different "strains" of prions. (B) Dimerisation occurs only through, or is greatly facilitated by, interaction with a third molecule, tentatively called factor $X$. It is possible that factor $X$ itself also causes tissue damage. 
occurrence of this disease in Great Britain (all but one patient were from the United Kingdom) in the wake of the BSE epidemic focused attention on a possible relation between the two, and some observations and subsequent experiments have strengthened this suspicion. Thus it has been shown that the trusted species barrier for BSE is considerably less safe than for scrapie. BSE is transmittable more easily and to far more species than scrapie, especially by the oral route, ${ }^{30}$ though oral transmission to primates is apparently less easy. ${ }^{31}$ Second, (intracerebral) inoculation of BSE material in primates produced a disease pathologically similar to the new variant CJD. ${ }^{32}$ And third, analysis of proteolysis and glycosylation patterns and, on a molecular level, of the different prion diseases inocula showed identical patterns for BSE and the new variant CJD..$^{33}$ Though this is not yet definitive proof for a relation, it certainly looks possible, though many more questions will have to be answered. We do not now how much infected material has entered the human food chain; we do not know for certain what parts of the infected animals are safe; we do not know whether prions can accumulate, so that repeated exposure to small doses can eventually cause the disease, or whether one large dose is required (if prions can cause human disease at all); we do not know if anyone can get the disease, and why some apparently have, while others are not (yet?) affected.

If, and how many, people are infected is still completely unclear. Perhaps the above mentioned polymorphism in the PrP molecule at codon 129 will be of major significance. Up to now all new variant CJD patients have been homozygous for methionine, and in the general population roughly one third of the people carry this phenotype. To the time of writing, 21 patients have been definitively diagnosed as new variant CJD-whether this number will rise dramatically or only a little, only the future will show.

\section{Transmission and transport}

Prion diseases can be transmitted through direct inoculation into the brain or a closely related organ such as the eye. The former is important in experimental settings and may explain CJD occurring after the use of infected electrodes or dura mater grafts; the latter explains CJD after corneal transplantation. The CJD cases occurring after growth hormone replacement treatment with cadaveric growth hormone show that the parenteral route is a possibility. ${ }^{12}{ }^{13}$ To this can be added the oral route; this was shown in kuru, and may now be the case in new variant CJD. However, it is clearly dependent on the material ingested. In the Fore tribe, kuru was prevalent mostly in women and children, as they ate the brains, while the men ate the muscles. Experiments with infectivity of different organs of BSE infected animals showed that infectivity is virtually restricted to the nervous system, with a very low infectivity for lymph nodes, spleen, and Peyer's patches, ${ }^{35}$ and muscle being fairly safe (even though PrP is expressed in skeletal muscle $\left.^{10}\right)$. These experiments were done, how- ever, using mice, and mice seem to be well protected by a species barrier. Experiments in cattle are awaited. Whether man is as well protected by a species barrier as the mouse is unknown. It is, however, disconcerting to learn how many "meat products" contain some animal nervous tissue. Furthermore, as already stated, the required dose to induce a prion diseases in humans is unknown.

Also unknown is the route of transmission of the agent from the digestive tract to the brain. Perhaps, however, the immune system is involved in this group of diseases after all. ${ }^{30} \mathrm{~A}$ diagnostic test for scrapie has been developed that can demonstrate PrP accumulation in tonsillar tissue of infected sheep and goats. ${ }^{36}$ Its use in humans is under investigation. ${ }^{37}$ The presence of PrP in the peripheral lymphoid tissue, apparently on the surface of follicular dendritic cells ${ }^{38}$ (judged non-mobile cells), suggests transport by immune cells, either macrophages or lymphocytes. ${ }^{39}$ This matter is under intense investigation.

\section{Consequences}

What are the implications of all of this, especially for the pathologist? Perhaps it is wise not to speak here of any dietary consequences. It is still a little early to put people off their steak and kidney pie. ${ }^{40}$ Or maybe it is even a little late. With the subsiding of the BSE epidemic, the amount of potentially infected meat entering the human food chain is also diminishing, though through a disturbing mixture of greed, stupidity, and ignorance potentially contaminated material appears to have been sold up to 1995. Clearly, more data are needed to make a realistic evaluation of risk in this area.

However, what about dealing with (potentially) infected material, during necropsy or handling of brain biopsies, and perhaps in the future, of tonsillar biopsies? Given the high profile of the prion diseases, we are almost certain to see more brain biopsies and more necropsies looking for CJD, classical or new variant. Fortunately, it is relatively rare for a case of CJD, old or new, to go completely unsuspected. Far more often the diagnosis is suspected, but histological and immunohistochemical evaluation will disprove it. The latter is essential, as spongiform changes can be subtle.

If a prion disease is suspected there is no reason to panic. There is, at the moment, a tendency to steer clear of anything remotely resembling a prion disease, by either refusing to perform a necropsy, or by referring the case to a centre where pathologists are interested in this subject, or are simply less squeamish. The former is perhaps not such a bad idea, but every pathologist should be able to handle the material to make sure it is adequately processed, so that a colleague in a centre can at least prove or disprove the diagnosis. It must also be pointed out that it is not possible to refuse biopsy material. A few simple guidelines ${ }^{41}$ are presented separately (box).

Perhaps it is reassuring to know that the incidence of CJD among health care workers is not higher than in the "normal" population, 
For biopsy material

(1) Fix tissue adequately, either in concentrated formic acid for one hour, followed by formalin for 48 hours minimum, or in a mixture of formalin and $0.1 \%$ hypochlorite $(1: 1)$ for at least 48 hours. After that the infectivity is destroyed and the material can be routinely processed.

(2) Clean instruments and surfaces with a hypochlorite solution or $2 \mathrm{~N}$ sodium hydroxide

For necropsies

(1) In opening the skull, use a plastic bag covering the head and electric saw, protecting the person handling it from aerosol spread; if not available, use a hand saw.

(2) Fix your tissue in a proper fixative. Formalin will only reduce prion infectivity slightly. However, submerging tissue samples in concentrated formic acid, or a mixture of $0.1 \%$ hypochlorite (household bleach) and formalin, for at least three hours will destroy the infectivity, while morphology remains more than adequate. Fixing entire brains in formic acid is impracticable, as the tissue becomes difficult to handle after prolonged exposure to formic acid. Here, the hypochlorite/formalin mixture is more practical.

(3) Clean instruments adequately. This means autoclaving for 60 minutes at $134^{\circ} \mathrm{C}$, or soak them in hypochlorite or $2 \mathrm{~N} \mathrm{NaOH}$ for three hours. Use disposables when possible.

(4) Clean surfaces, using $2 \mathrm{~N}$ sodium hydroxide, or hypochlorite. Don't use $\mathrm{NaOH}$ on aluminium materials!

and pathologists (one reported case) or histotechnicians (two reported cases) are not overrepresented among this group of cases. ${ }^{42}$

Given the potential implications of the BSE story, more research on the group of prion diseases is mandatory. We don't know what this research will bring, but it is not unlikely that this fascinating group of diseases will have additional surprises in store for us.

1 Gajdusek DC, Zigas V. Clinical, pathological, and epidemiological study of an acute progressive degenerative disease of logical study of an acute progressive degenerative disease of the central nervous system among natives of the eastern
highlands of New Guinea. Am 7 Med 1959;26:442-69.

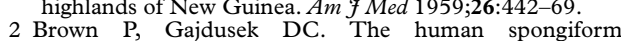
encephalopathies: kuru, Creutzfeldt-Jakob disease, and the encephalopathies: kuru, Creutzfeldt-Jakob disease, and the
Gerstmann-Straussler-Scheinker syndrome. Curr Top Gerstmann-Straussler-Scheinker
Microbiol Immunol 1991;172:1-20.

3 Hadlow WJ. The scrapie-kuru connection: recollections of how it came about. In: Prusiner SB, Collinge J, Powell J Anderton B, eds: Prion diseases of humans and animals. London: Ellis Harwood, 1992:40-6.

4 Wells GAH, McGill IS. Recently described scrapie-like encephalopathies of animals: case definitions. Res Vet Sci 1992;53:1-10.

5 Richardson EP, Masters CL. The nosology of CreutzfeldtJakob disease and conditions related to the accumulation of $\operatorname{PrP}^{\mathrm{CID}}$ in the nervous system. Brain Pathol 1995;5:33-41.

6 Ghetti B, Dlouhy SR, Giaccone G, et al. GerstmannStraussler-Scheinker disease and the Indiana kindred. Brain Pathol 1995;5:61-75.

7 Gambetti P, Parchi P, Petersen RB, et al. Fatal familial insomnia and familial Creutzfeldt-Jakob disease: clinical, pathological and molecular features. Brain Pathol 1995;5: pathologic
8 Wells GAH, Wilesmith JW. The neuropathology and epidemiology of bovine spongiform encephalopathy. Brain Pathol miology of bovine

9 Prusiner SB, DeArmond SJ. Molecular biology and pathology of scrapie and the prion diseases of humans. Brain Pathol 1991;1:297-310.

10 DeArmond SJ, Prusiner SB. Prion diseases. In: Graham DI, Lantos PL, eds. Greenfield's neuropathology, 6th ed, vol 2 . London: Arnold, 1997:235-80.

11 Alpers M. Reflections and highlights: a life with kuru. In: Prusiner SB, Collinge J, Powell J, Anderton B, eds. Prion diseases of humans and animals. New York: Ellis Horwood, 1992:66-76.

12 Will RG, Matthews WB. Evidence for case-to-case transmission of Creutzfeldt-Jakob disease. $\mathcal{F}$ Neurol Neurosurg Psychiatry 1982;45:235-8.

13 Brown P, Preece MA, Will RG. "Friendly fire" in medicine: hormones, homografts, and Creutzfeldt-Jakob disease. Lancet 1992;340:24-7.

14 Prusiner SB. Novel proteinaceous infectious particles cause crapie. Science 1982;216:136-44

15 Alper T, Cramp WA, Haig DA, et al. Does the scrapie agent replicate without nucleic acid? Nature 1967;214:764-6.

16 Bruce ME, Fraser H. Scrapie strain variation and its implications. Curr Top Microbiol Immunol 1991;172:125-38.

17 Manuelidis L, Fritch W, Xi Y-G. Evolution of a strain of CJD that induces BSE-like plaques. Science 1997;277:949.

18 McKinley MP, Bolton DC, Prusiner SB. A proteaseresistant protein is a structural component of the scrapie prion. Cell 1983;35:57-62.

19 Gasset M, Baldwin MA, Fletterick RJ, et al. Perturbation of the secondary structure of the scrapie prion protein under conditions associated with changes in infectivity. Proc Natl Acad Sci USA 1993;90:1-5.

20 Prusiner SB, Groth DF, Bolton DC, et al. Purification and structural studies of a major scrapie prion protein. Cell 1984;38:127-34.

21 Oesch B, Westaway D, Walchli M, et al. A cellular gene encodes scrapie PrP 27-30 protein. Cell 1985;40:735-46.

22 DeArmond SJ, Prusiner SB. Prion protein transgenes and the neuropathology in prion diseases. Brain Pathol 1995;5: 77-89.

23 Owen F, Poulter M, Collinge J, et al. Codon 129 changes in the prion protein gene in Caucasians. Am $\mathcal{F}$ Hum Genet 1990;46:1215-16.

24 Goldfarb LG, Petersen RB, Tabaton M, et al. Fatal familial insomnia and Familial Creutzfeldt-Jakob disease: disease phenotype determined by a DNA polymorphism. Science 1992;258:806-8.

25 Bueler H, Aguzzi A, Sailer A, et al. Mice devoid of PrP are resistant to scrapie. Cell 1993;73:1339-47.

26 Telling GC, Scott M, Hsiao KK, et al. Transmission of Creutzfeldt-Jakob disease from humans to transgenic mice Creutzfeldt-Jakob disease from humans to transgenic mice Natl Acad Sci USA 1994;91:9936-40.

27 Wells GAH, Scott AC, Johnson CT, et al. A novel progressive spongiform encephalopathy in cattle. Vet Rec 1987;121:419-20

28 Wilesmith JW, Wells GAH, Cranwell MP, et al. Bovine spongiform encephalopathy: epidemiological studies. Vet Rec 1988;123:638-44.

29 Will RG, Ironside JW, Zeidler M, et al. A new variant of Creutzfeldt-Jakob disease in the UK. Lancet 1996;347: 921-5.

30 Aguzzi A. Between cows and monkeys. Nature 1996;381: 734-5.

31 Ridley RM, Baker HF, Windle CP. Failure to transmit bovine spongiform encephalopathy to marmosets with bovine spongiform encephalopathy to ma

32 Lasmezas CI, Deslys J-P, Demaimay R, et al. BSE transmission to macaques. Nature 1996;381:743-4.

33 Collinge J, Sidle KC, Meads J, et al. Molecular analysis of prion strain variation and the aetiology of "new variant" CJD. Nature 1996;383:685-90.

34 Collinge J, Sidle KC, Meads J, et al. Molecular analysis of prion strain variation and the aetiology of 'new variant' CJD. Nature 1996;383:685-90

35 Brown P, Gibbs CJ, Rodgers-Johnson P, et al. Human spongiform encephalopathy: the National Institutes of Health series of 300 cases of experimentally transmitted disease. Ann Neurol 1994;35:513-29.

36 Keulen LJ van, Schreuder BE, Meloen RH, et al. Immunohistochemical detection of prion protein in lymphoid tissues of sheep with natural scrapie. F Clin Microbiol 1996; 34:1228-31.

37 Hill AF, Zeidler M, Ironside J, et al. Diagnosis of new variant Creutzfeldt-Jakob disease by tonsil biopsy. Lancet 1997;349:99-100.

38 Muramoto T, Kitamoto T, Tateishi J, et al. The sequential development of abnormal prion protein accumulation in mice with Creutzfeldt-Jakob disease. Am F Pathol 1992;140: 1411-20.

39 Aguzzi A. Neuro-immune connection in spread of prions in the body? Lancet 1997;349:742-3.

40 Collee JG, Bradley R. BSE: a decade on. Part 2. Lancet 1997;349:715-21.

41 Budka H, Aguzzi A, Brown P, et al. Tissue handling in suspected Creutzfeldt-Jakob disease (CJD) and other human spongiform encephalopathies (prion diseases). Brain Pathol 1995;5:319-22.

42 Berger JR, David NJ. Creutzfeldt-Jakob disease in a physician: a review of the disorder in health care workers. Neurology 1993;43:205-6. 